\title{
Mediterranean Diet and Cardiodiabesity: A Systematic Review through Evidence-Based Answers to Key Clinical Questions
}

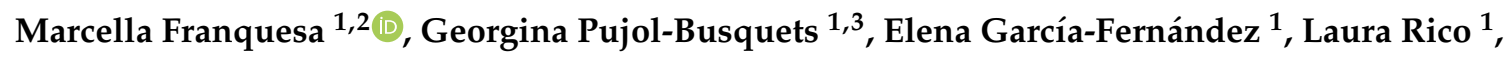 \\ Laia Shamirian-Pulido ${ }^{1}$, Alicia Aguilar-Martínez ${ }^{4}$, Francesc Xavier Medina ${ }^{4}$, \\ Lluís Serra-Majem ${ }^{5,6}($ D) and Anna Bach-Faig $4,7, *$ (D) \\ 1 Faculty of Health Sciences, Universitat Oberta de Catalunya (Open University of Catalonia, UOC), \\ 08018 Barcelona, Spain; mfranquesa@igtp.cat (M.F.); georgipbg@uoc.edu (G.P.-B.); \\ elenagf85@uoc.edu (E.G.-F.); lricoca@uoc.edu (L.R.); lshamirian@uoc.edu (L.S.-P.) \\ 2 REMAR-IVECAT Group, Health Science Research Institute Germans Trias i Pujol, Can Ruti Campus, \\ 08916 Badalona, Spain \\ 3 Division of Exercise Science and Sports Medicine, Department of Human Biology, Faculty of Health Sciences, \\ University of Cape Town, 7725 Cape Town, South Africa \\ 4 FoodLab Research Group (2017SGR 83), Faculty of Health Sciences, Universitat Oberta de Catalunya \\ (Open University of Catalonia, UOC), 08018 Barcelona, Spain; aaguilarmart@uoc.edu (A.A.-M.); \\ fxmedina@uoc.edu (F.X.M.) \\ 5 CIBER de Fisiopatología de la Obesidad y la Nutrición (CIBEROBN), Instituto de Salud Carlos III, \\ 28029 Madrid, Spain; lserra@dcc.ulpgc.es \\ 6 Research Institute of Biomedical and Health Sciences, University of Las Palmas de Gran Canaria, \\ 35001 Las Palmas de Gran Canaria, Spain \\ 7 Food and Nutrition Area, Barcelona Official College of Pharmacists, 08009 Barcelona, Spain \\ * Correspondence: abachf@uoc.edu
}

Received: 3 February 2019; Accepted: 13 March 2019; Published: 18 March 2019

\begin{abstract}
The Mediterranean Diet (MedDiet) has been promoted as a means of preventing and treating cardiodiabesity. The aim of this study was to answer a number of key clinical questions (CQs) about the role of the MedDiet in cardiodiabesity in order to provide a framework for the development of clinical practice guidelines. A systematic review was conducted to answer five CQs formulated using the Patient, Intervention, Comparison, and Outcome (PICO) criteria. Twenty articles published between September 2013 and July 2016 were included, adding to the 37 articles from the previous review. There is a high level of evidence showing that MedDiet adherence plays a role in the primary and secondary prevention of cardiovascular disease (CVD) and improves health in overweight and obese patients. There is moderate-to-high evidence that the MedDiet prevents increases in weight and waist circumference in non-obese individuals, and improves metabolic syndrome (MetS) and reduces its incidence. Finally, there is moderate evidence that the MedDiet plays primary and secondary roles in the prevention of type 2 diabetes mellitus (T2DM). The MedDiet is effective in preventing obesity and MetS in healthy and at-risk individuals, in reducing mortality risk in overweight or obese individuals, in decreasing the incidence of T2DM and CVD in healthy individuals, and in reducing symptom severity in individuals with T2DM or CVD.
\end{abstract}

Keywords: Mediterranean Diet; diabetes mellitus; cardiovascular disease; metabolic syndrome; obesity; cardiodiabesity; review; PICO 
experts with the basis for developing CPGs to promote the provision of evidence-based nutrition information and advice to patients with obesity, MetS, CVD, and T2DM.

\section{Materials and Methods}

\subsection{Literature Search}

A thorough search of prospective cohort, cross-sectional, and clinical trial studies in the scientific literature was conducted to gather evidence on the ability of the MedDiet to modulate or prevent diseases encompassed by the term cardiodiabesity. Using the same search strategies as García-Fernández et al. [6], the available evidence on the association between the MedDiet and cardiodiabesity was updated by reviewing studies published between September 2013 and July 2016. The literature search was performed in PubMed using the search term Mediterranean Diet and the key words Diabetes Mellitus, Coronary Disease, Myocardial Ischemia, Heart Disease, Metabolic Syndrome, and Obesity.

\subsection{Inclusion Criteria}

Five CQs were defined using the PICO framework (Table 1) [16-18]. As in the earlier review by García-Fernández et al. [6], only those studies relating to T2DM, obesity, MetS, and CVD were eligible for inclusion. In this study, we applied more stringent selection criteria (Table 2) to the articles from the previous study and to the new ones. The studies included were assigned one of three levels of evidence (Table 3) to answer the formulated CQs and to establish recommendations for the CPGs.

Table 1. Clinical questions (CQs) based on the Patient, Intervention, Comparison, and Outcome (PICO) method.

\begin{tabular}{|c|c|c|c|c|}
\hline $\begin{array}{l}\text { P: Who Are the } \\
\text { Patients/Participants } \\
\text { in the Study? }\end{array}$ & $\begin{array}{c}\text { I: What } \\
\text { Intervention Is } \\
\text { Being Examined? }\end{array}$ & $\begin{array}{l}\text { C: Against What is the } \\
\text { Intervention of Interest } \\
\text { Being Compared? }\end{array}$ & $\begin{array}{l}\text { O: What Are the } \\
\text { Measured Results } \\
\text { (Outcomes)? }\end{array}$ & CQs \\
\hline $\begin{array}{l}\text { Men and women with } \\
\text { overweight or obesity } \\
\text { and/or MetS }\end{array}$ & $\begin{array}{l}\text { Application of } \\
\text { MedDiet and/or } \\
\text { monitoring of } \\
\text { MedDiet adherence }\end{array}$ & $\begin{array}{l}\text { Epidemiologically similar } \\
\text { control group that does } \\
\text { not follow the MedDiet }\end{array}$ & $\begin{array}{l}\text { Reduction in } \\
\text { weight, BMI, } \\
\text { and/or WC }\end{array}$ & $\begin{array}{l}\text { CQ 1: What effect does the } \\
\text { MedDiet have on weight } \\
\text { reduction in overweight and } \\
\text { obese patients? }\end{array}$ \\
\hline $\begin{array}{l}\text { Men and women with } \\
\text { or at risk of T2DM }\end{array}$ & $\begin{array}{l}\text { Application of } \\
\text { MedDiet and/or } \\
\text { monitoring of } \\
\text { MedDiet adherence }\end{array}$ & $\begin{array}{l}\text { Epidemiologically similar } \\
\text { control group that does } \\
\text { not follow the MedDiet }\end{array}$ & $\begin{array}{l}\text { Reduction in risk of } \\
\text { all-cause mortality } \\
\text { and mortality due } \\
\text { to CVD, heart } \\
\text { attack, or T2DM }\end{array}$ & $\begin{array}{l}\text { CQ 2: What effect does the } \\
\text { MedDiet have on the incidence } \\
\text { and prevention of T2DM? }\end{array}$ \\
\hline $\begin{array}{l}\text { Healthy men and } \\
\text { women with MetS or } \\
\text { risk factors for MetS }\end{array}$ & $\begin{array}{l}\text { Application of } \\
\text { MedDiet and/or } \\
\text { monitoring of } \\
\text { MedDiet adherence }\end{array}$ & $\begin{array}{l}\text { Epidemiologically similar } \\
\text { control group that does } \\
\text { not follow the MedDiet }\end{array}$ & $\begin{array}{l}\text { Reduction in } \\
\text { incidence or } \\
\text { severity of MetS }\end{array}$ & $\begin{array}{l}\text { CQ 3: What effect does the } \\
\text { MedDiet have on established } \\
\text { MetS or on the risk of } \\
\text { developing MetS? }\end{array}$ \\
\hline Men and women & $\begin{array}{l}\text { Application of } \\
\text { MedDiet and/or } \\
\text { monitoring of } \\
\text { MedDiet adherence }\end{array}$ & $\begin{array}{l}\text { Epidemiologically similar } \\
\text { control group that does } \\
\text { not follow the MedDiet }\end{array}$ & $\begin{array}{l}\text { Reduction in CVD } \\
\text { incidence or } \\
\text { mortality }\end{array}$ & $\begin{array}{c}\text { CQ 4: What effect does the } \\
\text { MedDiet have on the prevention } \\
\text { of CVD and the modulation of } \\
\text { disease course? }\end{array}$ \\
\hline Men and women & $\begin{array}{l}\text { Application of } \\
\text { MedDiet and/or } \\
\text { monitoring of } \\
\text { MedDiet adherence }\end{array}$ & $\begin{array}{l}\text { Epidemiologically similar } \\
\text { control group that does } \\
\text { not follow the MedDiet }\end{array}$ & $\begin{array}{l}\text { Reduction in } \\
\text { weight gain, BMI, } \\
\text { or WC }\end{array}$ & $\begin{array}{l}\text { CQ 5: What effect does the } \\
\text { MedDiet have on weight gain and } \\
\text { abdominal adiposity in healthy } \\
\text { individuals and individuals } \\
\text { without overweight? }\end{array}$ \\
\hline
\end{tabular}


Table 2. Study selection criteria.

\begin{tabular}{|c|c|c|}
\hline Item & Inclusion Criteria & Exclusion Criteria \\
\hline Population & Adults (>18 years old) & $\begin{array}{c}\text { Children } \\
\text { Experimental animal studies }\end{array}$ \\
\hline Intervention & $\begin{array}{l}\text { Dietary interventions with the pure MedDiet } \\
\text { (defined in the study) or the MedDiet with } \\
\text { reinforcement of one of the food components (e.g., } \\
\text { olive oil or nuts) } \\
\text { No intervention (analysis of MedDiet adherence } \\
\text { [defined in the study]) }\end{array}$ & $\begin{array}{l}\text { Other food interventions and } \\
\text { interventions involving specific foods } \\
\text { even though they form part of the } \\
\text { MedDiet. Other non-dietary } \\
\text { interventions (e.g., pharmacological } \\
\text { or surgical). }\end{array}$ \\
\hline Comparator & $\begin{array}{l}\text { Non-dietary intervention, prudent diet, Westernized } \\
\text { diet, or any type of diet other than the MedDiet } \\
\text { Non-adherence to the MedDiet }\end{array}$ & \\
\hline Results (outcomes) & $\begin{array}{l}\text { Weight reduction measured as weight }(\mathrm{kg}, \mathrm{lb}, \%) \text {, } \\
\text { WC, hip-waist ratio, percentage of body fat, } \\
\text { maintenance of weight loss } \\
\text { Cardiovascular events: MI, heart failure, } \\
\text { hospitalization for MI or heart failure } \\
\text { Cardiovascular risk factors: total cholesterol factors, } \\
\text { HDL-C, LDL-C, non-HDL-C, triglycerides, diabetes, } \\
\text { smoking, CRP } \\
\text { Morbidity: cardiovascular damage, chronic renal } \\
\text { failure, non-alcoholic steatohepatitis, depression } \\
\text { Mortality: CVD, all causes } \\
\text { Changes in body composition: improved quality of } \\
\text { life, functionality, disability }\end{array}$ & Self-reported weight \\
\hline Time & $\begin{array}{c}\text { No time limits } \\
\text { Minimum 6-month follow-up }\end{array}$ & Fewer than 6 months of follow-up * \\
\hline Study design & Systematic reviews and clinical trials & Other \\
\hline Language & English & $\begin{array}{l}\text { Other (despite availability of an } \\
\text { English abstract) }\end{array}$ \\
\hline Publication type & Systematic reviews and meta-analyses & Other \\
\hline Publication date & From October 2013 to July 2016 & All others \\
\hline
\end{tabular}

Table 3. Levels of scientific evidence.

\begin{tabular}{ll}
\hline Study Characteristics & Level of Evidence \\
\hline - Well-designed, well-executed RCTs with assessment of health outcomes, & \\
representative of the populations to which the results apply & High \\
- $\quad$ Meta-analyses of the aforementioned RCTs & \\
research on the subject would alter this certainty & Moderate \\
\hline - $\quad$ RCTs with minor limitations affecting applicability of or confidence in the results & \\
- $\quad$ Meta-analysis of the aforementioned RCTs & \\
the subject would alter this certainty & \\
- $\quad$ RCTs with major limitations & Low \\
- Non-RCTs and observational studies with major constraints affecting applicability of & \\
or confidence in the results & \\
- Uncontrolled clinical studies without an adequate comparison group & \\
- Psychological studies in humans and meta-analyses of these & \\
- Low certainty about the estimated effects and strong likelihood that more research on & \\
the subject would alter this certainty &
\end{tabular}


The literature search was limited to human studies published in English. The search in the original review retrieved 740 articles, of which 523 were excluded based on the title. Of the remaining 217 articles, 122 were excluded after reading the abstract, and 58 after reading the full text and taking into account the selection criteria specified in Table 2. This left 30 articles: Seven on MetS, nine on obesity, four on T2DM, and 10 on CVD [6] (Figure 2).

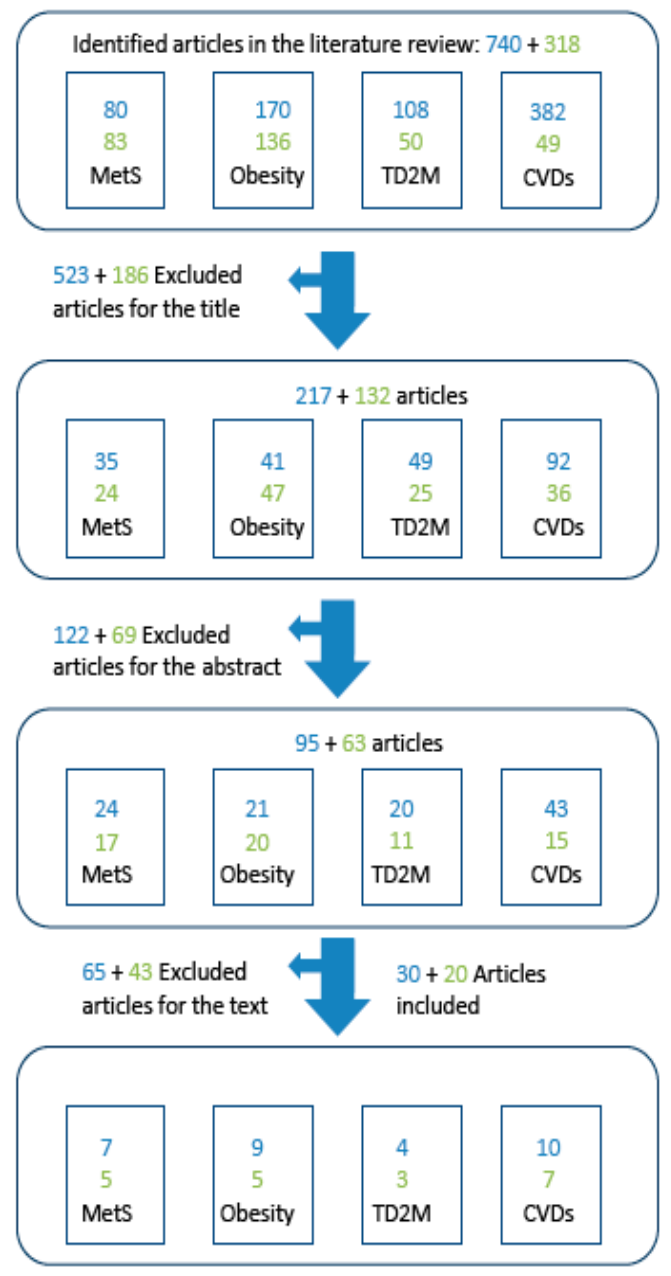

Figure 2. Selection process for studies included in the systematic review. The numbers in blue refer to the articles included and excluded by García-Fernández et al. [6]. The numbers in green refer to the additional articles included in and excluded from this updated review.

\section{Results}

The new search retrieved 318 articles, of which 186 were excluded on screening the title. Of the remaining 132 articles, 69 were excluded after reading the abstract, and 43 after reading the full text, leaving 20 articles: Five on MetS, five on obesity, three on T2DM, and seven on CVD (Figure 2). Thus, the total number of articles included in the current review was 50: 30 from the original review and 20 from the updated one. Of these, 12 were on MetS, 14 on obesity, seven on T2DM, and 17 on CVD (Tables 4 and 5). The five CQs were addressed based on different levels of scientific evidence. The level of evidence for each question is shown below, together with the corresponding rationale.

\subsection{CQ 1: What Effect Does the MedDiet Have on Weight Reduction in Overweight and Obese Patients?}

Level of evidence: High

- MedDiet adherence reduces obesity and abdominal adiposity 
Rationale: A reduction in obesity and abdominal adiposity is a well-reported effect of the MedDiet in controlled clinical trials and prospective studies. A small study in Italy showed that obese women with greater adherence to a moderately hypocaloric MedDiet experienced a significant reduction in weight and BMI (body mass index) [19]. A subsequent Croatian dietary intervention study showed that higher MedDiet adherence favored greater weight loss in obese people than a low-fat diet [20]. In Spain, several sub-studies within the PREDIMED (PREvención con DIeta MEDiterránea [Prevention with a Mediterranean Diet]) clinical trial have shown that MedDiet adherence is associated with a lower level of inflammation [21] and a greater reduction in total weight, WC (waist circumference), BMI (especially for those following a MedDiet supplemented with extra-virgin olive oil) [22,23], and blood pressure, as well as increased levels of high-density lipoprotein cholesterol (HDL-C) [24].

\section{- The MedDiet reduces CVD incidence and mortality}

Rationale: Until just a few years ago, the American Heart Association recommended a low-fat diet in overweight patients with high cardiovascular risk [25]. Data, however, from the PREDIMED cohort, widely demonstrated the superiority of the MedDiet in reducing CVD risk and mortality in individuals without CVD but with other baseline risk factors [26]. A systematic review by Nissensohn et al. [27] of the effects of the MedDiet and a low-fat diet also found evidence of an association between the MedDiet and a reduction in systolic and diastolic blood pressure. Higher MedDiet adherence has also been linked to a reduction in CVD risk and mortality in the general population (including obese and non-obese individuals) without CVD [28-39].

\subsection{CQ 2: What Effect Does the MedDiet Have on the Incidence and Prevention of T2DM?}

Level of evidence: Moderate

\section{- The MedDiet reduces the incidence of T2DM in healthy individuals}

Rationale: Several studies have shown a reduction in the risk of de novo T2DM in healthy individuals with high MedDiet adherence [40-43]. By contrast, a meta-analysis found no evidence of differences between the MedDiet and control diets in terms of their effect on the risk of T2DM in non-diabetic individuals [44]. Abiemo et al. [45] studied the effect of the MedDiet in the general population and found that it reduced glucose and insulin levels, but not the incidence of T2DM in non-diabetics.

- The MedDiet reduces the symptoms of T2DM and modulates disease course

Rationale: MedDiet adherence has been found to reduce glycated hemoglobin (HbA1c) [43,44], CRP (C-reactive protein), and adiponectin [46] levels in diabetic patients.

\subsection{CQ 3: What Effect Does the MedDiet Have on Established MetS or on the Risk of Developing MetS?}

Level of evidence: Moderate-to-high

\section{- High MedDiet adherence decreases some risk factors for MetS}

Rationale: MedDiet adherence, compared against a control diet, has been found to reduce WC and blood pressure, and to increase HDL-C levels [24,47]. Other studies have found no association between the MedDiet and the prevalence of MetS, although some components of the diet showed a protective effect on MetS and its components [48].

\section{- The MedDiet reduces some risk factors for MetS in healthy individuals}

Rationale: Steffen et al. [49] showed that the incidence of MetS in healthy individuals was inversely proportional to the level of MedDiet adherence. Individuals with lower adherence showed greater abdominal adiposity and a higher percentage of low HDL-C levels over a period of 25 years. Similarly, Rumawas et al. [50] reported that individuals with greater MedDiet adherence had a significantly lower incidence of MetS in addition to lower WC and triglyceride levels, and higher 
HDL-C levels after 7 years of follow-up. These findings were corroborated by Kess-Guyot et al. [51]. Mirmiran et al. [52], in turn, in a prospective analysis of the MedDiet modified for the Iranian population that took into account the ratio of monounsaturated fatty acids (MUFAs) to polyunsaturated fatty acids (PUFAs) instead of olive oil consumption, found no evidence of an association between MedDiet adherence and incidence of MetS. Another prospective study by Alvarez-Leon et al. [48], which also studied the MUFA/PUFA ratio rather than olive oil consumption, also found no association between MedDiet adherence and incidence of MetS.

\subsection{CQ 4: What Effect Does the MedDiet Have on the Prevention of CVD and the Modulation of Disease Course?} Level of evidence: High

- MedDiet adherence reduces the incidence of CVD in individuals with high cardiovascular risk

Rationale: The protective role of the MedDiet on the incidence of cardiovascular events has been widely demonstrated in large clinical trials [28,30,35,37,39,53-55]. Furthermore, Estruch et al. [26] showed that, compared against the low-fat diet recommended by the American Heart Association, the MedDiet supplemented with nuts or extra-virgin olive oil protected high-risk individuals from CVD. A meta-analysis of 20 studies containing data from 888,257 individuals by Grosso et al. [56] showed that increased MedDiet adherence was associated with a relative risk reduction of $40 \%$ for CVD incidence.

- MedDiet adherence reduces CVD mortality in individuals without CVD but with high cardiovascular risk

Rationale: Several studies have reported an association between the MedDiet and a reduction in CVD mortality in individuals with risk factors for CVD [37-39]. Bonaccio et al. [38], in turn, showed that high MedDiet adherence was associated with a relative risk reduction of $34 \%$ for CVD mortality in patients with T2DM.

- MedDiet adherence reduces CVD incidence and mortality in the general population

Rationale: MedDiet intervention studies in the general population without baseline data on health status have concluded that adherence to the diet has a protective effect on CVD incidence and mortality [31-33,36,37,57,58]. A study by Fung et al. [32] of women with T2DM without a history of CVD also showed that high MedDiet adherence protected against CVD risk and associated mortality. Similarly, Knoop et al. [59] showed that higher MedDiet adherence was associated with reduced CVD-specific and all-cause mortality in the elderly population (70-90 years).

3.5. CQ 5: What Effect Does the MedDiet Have on Weight Gain and Abdominal Adiposity in Healthy Individuals and Individuals Without Overweight?

Level of evidence: Moderate-to-high

\section{- MedDiet adherence decreases weight gain and BMI in the general population}

Rationale: Several studies have shown that high MedDiet adherence reduces weight gain and BMI in the general population in the long term [60-62]. An additional study by Paletas et al. [63] reported that MedDiet adherence contributed to weight control in individuals who were overweight at baseline. This effect was not observed for those with normal weight.

- MedDiet adherence reduces WC in the general population

Rationale: Studies by Rumawas et al. [50] and Steffen et al. [49] showed that individuals with high MedDiet adherence have a smaller WC. Romaguera et al. [64] also observed this finding in individuals with a BMI between 20.09 and 20.17. 
Table 4. Articles included in this review published between October 2013 and July 2016.

\begin{tabular}{|c|c|c|c|c|c|c|c|c|c|}
\hline Author, Year & Type of Study & Country & $\begin{array}{l}\text { Sex, Age (y) and Number of } \\
\text { Participants }\end{array}$ & Initial Disease & Follow-Up (y) & $\begin{array}{l}\text { Components of } \\
\text { MedDiet Index }\end{array}$ & Object of Study & Results & Confounders \\
\hline $\begin{array}{l}\text { Ruiz-Canela et al., } \\
2015 \text { [21] }\end{array}$ & $\begin{array}{l}\text { Multicenter parallel-group RCT } \\
\text { (PREDIMED) }\end{array}$ & Spain & $\begin{array}{l}3111 \text { men (ages 55-80) } \\
4125 \text { women (ages 60-80) } \\
\mathrm{N} \text { total }=7236\end{array}$ & $\begin{array}{l}\text { No CVD or T2DM but three } \\
\text { risk factors for CVD: } \\
\text { smoking, hypertension, high } \\
\text { LDL-C, low HDL-C, BMI } \geq \\
25 \mathrm{~kg} / \mathrm{m}^{2} \text {, family history of } \\
\text { premature CVD }\end{array}$ & - & $\begin{array}{l}\text { PREDIMED } \\
\text { [26] }\end{array}$ & Obesity & $\begin{array}{c}\text { Adjusted difference in } \mathrm{WHtR} \text { for } \\
\text { women and men between the } \\
\text { highest and lowest quintiles of DII: } \\
1.60 \%(95 \% \mathrm{CI}, 0.87-2.33) \text { and } \\
1.04 \%(95 \% \mathrm{CI}, 0.35-1.74) \\
\text { respectively }\end{array}$ & \\
\hline $\begin{array}{l}\text { Nissensohn et al., } \\
\quad 2015[27]\end{array}$ & $\begin{array}{l}\text { Systematic review and } \\
\text { meta-analysis }\end{array}$ & Spain & $\begin{array}{l}\text { Men and women } \\
\text { (age not specified) } \\
\mathrm{N} \text { total }>7000\end{array}$ & $\begin{array}{l}\text { Different depending on } \\
\text { the study }\end{array}$ & $>2$ & $\begin{array}{l}\text { Different depending on } \\
\text { the study }\end{array}$ & Cardiodiabesity & $\begin{array}{l}\text { MedDiet vs. low-fat diet: decrease } \\
\text { in systolic and diastolic } \\
\text { blood pressure }\end{array}$ & \\
\hline $\begin{array}{l}\text { Eguaras et al., } \\
2015[54]\end{array}$ & RCT (PREDIMED) & Spain & $\begin{array}{l}3241 \text { men (ages 55-80) } \\
4297 \text { women (ages 60-80) } \\
\mathrm{N} \text { total }=7538\end{array}$ & $\begin{array}{l}\text { High risk of CVD due to } \\
\text { T2DM or presence of three } \\
\text { risk factors for CVD }\end{array}$ & 4.8 & $\begin{array}{l}\text { PREDIMED } \\
\text { [26] }\end{array}$ & Obesity and CVD & $\begin{array}{c}\text { Increased risk of CVD events was } \\
\text { apparent for the highest vs. the } \\
\text { lowest quartiles of WHtR (HR, } \\
1.98 ; 95 \% \text { CI, } 1.10-3.57 ; \text { linear } \\
\text { trend: } p=0.019 \text { ) only in control } \\
\text { diet group }\end{array}$ & $\begin{array}{l}\text { Age, sex, } \\
\text { multivariate }\end{array}$ \\
\hline $\begin{array}{l}\text { Hadziabdic et al., } \\
\quad 2016[20]\end{array}$ & Parallel-group RCT & Croatia & $\begin{array}{l}\text { Men and women (ages 18-69) } \\
\quad \mathrm{N} \text { total }=84\end{array}$ & $\begin{array}{c}\text { Obesity } \\
\left(\geq 30 \mathrm{~kg} / \mathrm{m}^{2}\right)\end{array}$ & 1 & $\begin{array}{l}\text { (+) vegetables, fruit, } \\
\text { whole grains, }(-) \text { red } \\
\text { meat }(+) \text { fish and } \\
\text { poultry. } 1573 \mathrm{kcal} / \mathrm{day} \\
33 \mathrm{~g} \text { of olive oil /day } \\
\text { and } 56 \mathrm{~g} \text { of nuts } / \text { week }\end{array}$ & Obesity & $\begin{array}{l}\text { MedDiet vs. low-fat diet: tendency } \\
\text { towards high weight loss }(\mathrm{kg})\end{array}$ & \\
\hline $\begin{array}{l}\text { Alvarez-Perez et al., } \\
\quad 2016 \text { [22] }\end{array}$ & $\begin{array}{l}\text { Multicenter, parallel-group RCT } \\
\text { (PREDIMED) }\end{array}$ & Spain & $\begin{array}{l}\text { Men (ages 55-80) and women } \\
(\text { ages } 60-80) \\
\mathrm{N} \mathrm{total}=305\end{array}$ & $\begin{array}{l}\text { No CVD or T2DM but three } \\
\text { risk factors for CVD: } \\
\text { smoking, hypertension, high } \\
\text { LDL-C, low HDL-C, } \\
\text { overweight/obesity, family } \\
\text { history of premature CVD }\end{array}$ & 1 & $\begin{array}{l}\text { PREDIMED } \\
\text { [26] }\end{array}$ & Obesity & $\begin{array}{l}\text { Low-fat diet decreased total body } \\
\text { weight but increased total body fat. } \\
\text { MedDiet + nuts decreased total } \\
\text { body weight. MedDiet + } \\
\text { extra-virgin olive oil decreased } \\
\text { total body weight, BMI, and WC. }\end{array}$ & Sex and age \\
\hline $\begin{array}{l}\text { Casas et al., } \\
2014[55]\end{array}$ & $\begin{array}{l}\text { Parallel-group RCT } \\
\text { (PREDIMED) }\end{array}$ & Spain & $\begin{array}{l}77 \text { men and } 87 \text { women } \\
\text { (average age } 67.7 \text { ) } \\
\mathrm{N} \text { total }=164\end{array}$ & $\begin{array}{l}\text { No CVD or T2DM but three } \\
\text { risk factors for CVD: } \\
\text { smoking, hypertension, high } \\
\text { LDL-C, low HDL-C, BMI } \geq \\
25 \mathrm{~kg} / \mathrm{m}^{2} \text {, family history of } \\
\text { premature CVD }\end{array}$ & 1 & $\begin{array}{l}\text { PREDIMED } \\
\text { [26] }\end{array}$ & CVD & $\begin{array}{l}\text { MedDiet reduced systolic ( } p=0.02) \\
\text { and diastolic }(p=0.02) \text { blood } \\
\text { pressure, total cholesterol }(p=0.04) \\
\text { and LDL-C by 5-9\% }(p=0.04) \text {. } \\
\text { MedDiet significantly reduced } \\
\text { inflammatory markers (e.g., } \\
\text { VCAM and ICAM) and adhesion } \\
\text { molecules (e.g., CD40). }\end{array}$ & \\
\hline $\begin{array}{l}\text { Grosso et al., } \\
2015 \text { [56] }\end{array}$ & $\begin{array}{l}\text { Systematic review and } \\
\text { meta-analysis (20 studies) }\end{array}$ & Several & $\begin{array}{l}\text { Men and women (ages 20-70) } \\
\mathrm{N} \text { total }=888,257\end{array}$ & $\begin{array}{l}\text { Established CVD, risk factors } \\
\text { for CVD, elderly }\end{array}$ & - & MedDiet & CVD & $\begin{array}{l}\text { Higher MedDiet adherence was } \\
\text { associated with a } 40 \% \text { relative risk } \\
\text { reduction in CVD incidence and } \\
\text { mortality. Reduced CVD risk for } \\
\text { consumption of olive oil, } \\
\text { vegetables, fruit, and pulses, } \\
\text { and increased CVD risk for } \\
\text { consumption of dairy products. } \\
\text { No difference for consumption of } \\
\text { fish, alcohol, cereals, or red meat. }\end{array}$ & \\
\hline
\end{tabular}


Table 4. Cont.

\begin{tabular}{|c|c|c|c|c|c|c|c|c|c|}
\hline Author, Year & Type of Study & Country & $\begin{array}{l}\text { Sex, Age (y) and Number of } \\
\text { Participants }\end{array}$ & Initial Disease & Follow-Up (y) & $\begin{array}{l}\text { Components of } \\
\text { MedDiet Index }\end{array}$ & Object of Study & Results & Confounders \\
\hline $\begin{array}{l}\text { Bonaccio et al., } \\
2014 \text { [38] }\end{array}$ & Cohort study & Italy & $\begin{array}{l}139 \text { men and } 643 \text { women } \\
\text { (average age 62.6) } \\
\mathrm{N} \text { total }=1995\end{array}$ & $\begin{array}{l}\text { T2DM at the beginning of the } \\
\text { study }\end{array}$ & 4 & $\begin{array}{l}\text { EPIC-Trichopoulou } \\
\text { score [65] }\end{array}$ & $\begin{array}{l}\text { CVD and } \\
\text { mortality }\end{array}$ & $\begin{array}{l}\text { Higher MedDiet adherence was } \\
\text { associated with a } 37 \% \text { relative risk } \\
\text { reduction in CVD mortality and a } \\
34 \% \text { relative risk reduction in } \\
\text { cerebrovascular-event mortality. } \\
\text { Adherence to consumption of } \\
\text { vegetables and olive oil reduced } \\
\text { mortality by } 21 \% \text {. A reduction was } \\
\text { observed only when CVD } \\
\text { mortality was considered (HR, } \\
0.66 ; 0.46-0.95) \text {. The MedDiet was } \\
\text { associated with a reduced risk of } \\
\text { death overall (HR, } 0.81 ; 0.62-1.07) \text {. }\end{array}$ & $\begin{array}{c}\text { Age, sex, } \\
\text { education, } \\
\text { oil intake, } \\
\text { blood glucose }\end{array}$ \\
\hline Menotti 2015 [59] & $\begin{array}{l}\text { Prospective study of MedDiet } \\
\text { adherence and lifestyle in Seven } \\
\text { Countries } \\
\text { CVD study }\end{array}$ & Italy & $\begin{array}{c}\text { Men and women (age up to 90) } \\
\mathrm{N} \text { total }=1677\end{array}$ & General rural population & $\leq 50$ & $\begin{array}{l}\text { MedDiet: } 18 \text { food } \\
\text { groups [29] }\end{array}$ & CVD & $\begin{array}{l}\text { MedDiet adherence was associated } \\
\text { with lower CVD incidence. } \\
\text { Cox proportional HRs for CHD: } \\
1.45(95 \%, \mathrm{Cl}, 1.11-1.90) \text { for heavy } \\
\text { smokers vs. non-smokers; } 0.67 \\
(95 \% \text { CI, } 0.50-0.89) \text { for vigorous } \\
\text { activity vs. sedentary habits, } \\
\text { and } 0.62 \text { ( } 95 \% \text { CI, } 0.47-0.83) \text { for } \\
\text { MedDiet vs. non-MedDiet. }\end{array}$ & $\begin{array}{l}\text { Smokers and } \\
\text { physical } \\
\text { activity }\end{array}$ \\
\hline $\begin{array}{l}\text { Stefler et al., } \\
2015[39]\end{array}$ & $\begin{array}{l}\text { Prospective study of HAPIEE } \\
\text { cohort }\end{array}$ & $\begin{array}{l}\text { Poland, } \\
\text { Russia, } \\
\text { and Czech } \\
\text { Republic }\end{array}$ & $\begin{array}{l}8787 \text { men and } 10,546 \text { women } \\
\text { (age not specified) } \\
\text { N total }=19,333\end{array}$ & $\begin{array}{c}\text { Absence of CVD and } \\
\text { diabetes }\end{array}$ & 7 & $\begin{array}{l}\text { MedDiet } \\
\text { recommendations [66] } \\
\text { with categorization of } \\
17 \text { points }\end{array}$ & CVD & $\begin{array}{c}\text { One SD increase in MDS inversely } \\
\text { associated with all-cause mortality } \\
\text { (HR, } 0.93 ; 95 \% \mathrm{CI}, 0.88-0.98 \text { ) and } \\
\text { CVD (HR, } 0.90 ; 95 \% \mathrm{CI}, 0.81-0.99) . \\
\text { Inverse but non-significant link } \\
\text { found for CHD (HR, 0.90; } 95 \% \text { CI, } \\
0.78-1.03 \text { ) and stroke (HR, } 0.87 \text {; } \\
95 \% \text { CI, } 0.71-1.07) . \\
\end{array}$ & \\
\hline $\begin{array}{l}\text { Turati et al., } \\
2015[36]\end{array}$ & Prospective cohort study (EPIC) & Greece & $\begin{array}{c}8246 \text { men and } 12,029 \text { women } \\
\text { (ages } 20-86) \\
\mathrm{N} \text { total }=20,275\end{array}$ & $\begin{array}{l}\text { Absence of CVD, cancer, } \\
\text { and diabetes }\end{array}$ & 10.4 & $\begin{array}{l}\text { MedDiet defined } \\
\text { according to } \\
\text { Trichopoulou [65] }\end{array}$ & CVD & $\begin{array}{l}\text { Significant positive association } \\
\text { between glycemic load and CHD } \\
\text { incidence (HR for highest vs. } \\
\text { lowest tertiles, }, .141 \text {; } 95 \% \text { CI } \\
1.05-1.90) \text {. High MedDiet } \\
\text { adherence with low/moderate } \\
\text { glycemic load associated with } \\
\text { lower risk of CHD incidence (HR, } \\
0.61 ; 95 \% \mathrm{CI}, 0.39-0.95) \text { and } \\
\text { mortality (HR, } 0.47 ; 95 \% \mathrm{CI}, \\
0.23-96) .\end{array}$ & Sex, BMI \\
\hline
\end{tabular}


Table 4. Cont.

\begin{tabular}{|c|c|c|c|c|c|c|c|c|c|}
\hline Author, Year & Type of Study & Country & $\begin{array}{c}\text { Sex, Age (y) and Number of } \\
\text { Participants }\end{array}$ & Initial Disease & Follow-Up (y) & $\begin{array}{l}\text { Components of } \\
\text { MedDiet Index }\end{array}$ & Object of Study & Results & Confounders \\
\hline $\begin{array}{l}\text { Stewart et al., } \\
2016[37]\end{array}$ & RCT & 30 countries & $\begin{array}{l}\text { 12,556 men and } 2926 \text { women } \\
\text { (average age 64.2) } \\
\mathrm{N} \text { total }=15,482\end{array}$ & $\begin{array}{c}\text { Previous MI with a risk } \\
\text { factor: }>60 \text { years, DM under } \\
\text { treatment, HDL-C< } \\
1.03 \mathrm{mmol} / \mathrm{L} \text {, smoker or } \\
\text { ex-smoker, glomerular } \\
\text { filtration rate }>30< \\
60 \mathrm{~mL} / \mathrm{min} \text { or albuminuria } \\
\text { or polyvascular disease }\end{array}$ & 3.7 & $\begin{array}{l}\text { MedDiet defined } \\
\text { according to Turati [36]. } \\
\text { Eggs and dairy } \\
\text { products not included. }\end{array}$ & CVD & $\begin{array}{c}\text { MedDiet adherence (MDS > 12) } \\
\text { associated with lower CVD } \\
\text { incidence and mortality. } \\
\text { One-unit increase in MDS > } \\
12 \text { associated with lower MACE } \\
\text { after adjusting for all covariates } \\
(+1 \text { category } \mathrm{HR}, 0.95 ; 95 \% \mathrm{CI}, \\
0.91-0.98, p=0.02) \text {. } \\
\text { No association between Western } \\
\text { diet score (adjusted model } \\
+1 \text { category HR, } 0.99 ; 95 \% \mathrm{CI}, 0.97- \\
\text { 1.01) and MACE. }\end{array}$ & $\begin{array}{l}\text { Geography, } \\
\text { education }\end{array}$ \\
\hline $\begin{array}{l}\text { Esposito et al., } \\
2015[43]\end{array}$ & $\begin{array}{l}\text { Systematic review and } \\
\text { meta-analysis }\end{array}$ & Several & $\begin{array}{l}\text { Men and women } \\
\text { (age not specified) } \\
\mathrm{N} \text { total }=1266\end{array}$ & $\begin{array}{l}\text { Overweight or obesity } \\
\text { with T2DM }\end{array}$ & $>0.5$ & $\begin{array}{c}\text { MedDiet defined } \\
\text { according to } \\
\text { PREDIMED [26] }\end{array}$ & T2DM & $\begin{array}{l}\text { Higher MedDiet adherence } \\
\text { lowered HbAlc. MedDiet reduced } \\
\text { incidence of T2DM. }\end{array}$ & \\
\hline Sleiman et al., [44] & Systematic review & Several & $\begin{array}{l}\text { Men and women } \\
\text { (age not tspecified) } \\
\mathrm{N} \text { total }=1266\end{array}$ & $\begin{array}{l}\text { Obesity with T2DM and } \\
\text { non-high-risk diabetes }\end{array}$ & $0.5-2$ & $\begin{array}{l}\text { Different depending } \\
\text { on study }\end{array}$ & T2DM & $\begin{array}{l}\text { Fasting glucose increased and } \\
\text { HbA1c decreased in individuals } \\
\text { following the MedDiet. } \\
\text { No differences for MedDiet and } \\
\text { control diet in } \\
\text { non-diabetic patients. }\end{array}$ & \\
\hline $\begin{array}{l}\text { Maiorino et al., } \\
2016[46]\end{array}$ & Parallel-group RCT (MEDITA) & Italy & $\begin{array}{l}\text { Men and women } \\
\text { (age not specified) } \\
\mathrm{N} \text { total }=215\end{array}$ & Recent diagnosis of T2DM & 8.1 & MedDiet & T2DM & $\begin{array}{l}\text { MedDiet decreased CRP and } \\
\text { increased adiponectin }\end{array}$ & \\
\hline $\begin{array}{l}\text { Babio et al., } \\
2014[23]\end{array}$ & $\begin{array}{l}\text { Multicenter, parallel-group RCT } \\
\text { (PREDIMED) }\end{array}$ & Spain & $\begin{array}{l}2437 \text { men (ages 55-80) and } \\
3364 \text { women (ages } 60-80) \\
\text { N total }=5801\end{array}$ & $\begin{array}{l}\text { No CVD or T2DM but three } \\
\text { risk factors for CVD: } \\
\text { smoking, hypertension, high } \\
\text { LDL-C, low HDL-C, BMI } \geq \\
25 \mathrm{~kg} / \mathrm{m}^{2} \text {, family history of } \\
\text { premature CVD }\end{array}$ & 4.8 & PREDIMED [26] & MetS & 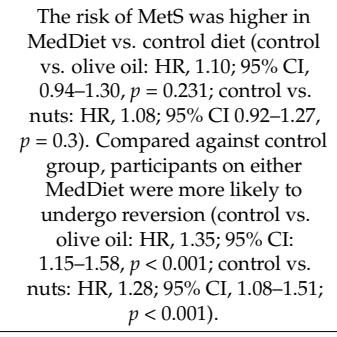 & \\
\hline $\begin{array}{l}\text { Steffen et al., } \\
2014[49]\end{array}$ & $\begin{array}{l}\text { Prospective study of MedDiet } \\
\text { adherence and CVD (CARDIA) }\end{array}$ & USA & $\begin{array}{c}2140 \text { men and } 2573 \text { women (ages } \\
18-30 \text { at the beginning of } \\
\text { the study) } \\
\mathrm{N} \text { total }=4713\end{array}$ & Absence of MetS & 25 & $\begin{array}{l}\text { Modified by } \\
\text { Trichopoulou [65] }\end{array}$ & MetS & $\begin{array}{c}\text { Incidence of MetS inversely } \\
\text { proportional to MedDiet } \\
\text { adherence. Lower adherence } \rightarrow \\
\text { higher abdominal adiposity and } \% \\
\text { low HDL-C. } \\
\text { The HRs and } 95 \% \text { CI from } \\
\text { category } 1 \text { to category } 5 \text { were } 1.0 ; \\
0.94(0.76,1.15) ; 0.84(0.68,1.04) ; \\
0.73(0.58,0.92) ; \text { and } 0.72(0.54, \\
0.96), \text { respectively }(p=0.005) .\end{array}$ & $\begin{array}{l}\text { Age, } \\
\text { education, } \\
\text { physical } \\
\text { activity, } \\
\text { and race }\end{array}$ \\
\hline
\end{tabular}


Table 4. Cont

\begin{tabular}{|c|c|c|c|c|c|c|c|c|c|}
\hline Author, Year & Type of Study & Country & $\begin{array}{l}\text { Sex, Age (y) and Number of } \\
\text { Participants }\end{array}$ & Initial Disease & Follow-Up (y) & $\begin{array}{l}\text { Components of } \\
\text { MedDiet Index }\end{array}$ & Object of Study & Results & Confounders \\
\hline $\begin{array}{l}\text { Gomez-Huelgas } \\
2015 \text { [24] }\end{array}$ & $\begin{array}{l}\text { Cross-sectional study to } \\
\text { determine prevalence of MetS }\end{array}$ & Spain & $\begin{array}{l}55.1 \% \text { men and } 44.9 \% \text { women } \\
\text { (average age } 53.8 \text { ) } \\
\mathrm{N} \text { total }=406\end{array}$ & $\begin{array}{l}\text { MetS as defined by the } \\
\text { International Society of } \\
\text { Diabetes }\end{array}$ & 3 & $\begin{array}{l}\text { MedDiet (14 points) } \\
\text { according to } \\
\text { PREDIMED }\end{array}$ & MetS & $\begin{array}{l}\text { MedDiet } \rightarrow \text { greater decrease in } \\
\text { WC and blood pressure and higher } \\
\text { HDL than the control group. }\end{array}$ & \\
\hline $\begin{array}{l}\text { Mirmiran et al., } \\
2015 \text { [52] }\end{array}$ & $\begin{array}{c}\text { Prospective study to } \\
\text { identify and prevent } \\
\text { non-communicable diseases }\end{array}$ & Iran & $\begin{array}{l}\text { 44.8\% men and } 55.2 \% \text { women } \\
\text { (average age } 39.1 \text { ) } \\
\text { N total = } 2241\end{array}$ & $\begin{array}{l}\text { Healthy individuals without } \\
\text { T2DM or MetS }\end{array}$ & 3 & $\begin{array}{l}\text { MedDiet defined } \\
\text { according to } \\
\text { Trichopoulou [65]. } \\
\text { MUFA/PUFA ratio; no } \\
\text { olive oil intake }\end{array}$ & MetS & $\begin{array}{l}\text { In the multivariable model, } \\
\text { the adjusted odds ratio (OR) for } \\
\text { developing Mets did not differ } \\
\text { significantly between participants } \\
\text { in the highest MDS tertile (OR, } \\
0.88 \text {, } 95 \% \text { CII } 0.62-1.23 \text { or } \\
\text { Sofi-MDS (OR, 1.12; } 95 \% \text { CI, } \\
0.77-1.62) \text { and those in the } \\
\text { lowest tertiles. }\end{array}$ & $\begin{array}{l}\text { Age, sex, } \\
\text { intake, } \\
\text { physical } \\
\text { activity, } \\
\text { smoker, BMI }\end{array}$ \\
\hline $\begin{array}{l}\text { Kastorini et al., } \\
2016[35]\end{array}$ & ATTICA & Greece & $\begin{array}{l}50 \% \text { men and } 50 \% \text { women } \\
\text { (ages } 18-89) \\
\mathrm{N} \text { total }=2020\end{array}$ & Absence of CVD & 8.41 & MedDiet & MetS and CVD & $\begin{array}{l}10 \% \text { increase in MedDiet } \\
\text { adherence associated with } 15 \% \\
\text { less probability of developing } \\
\text { CVD. Individuals with low } \\
\text { MedDiet adherence were twice as } \\
\text { likely to develop MetS. } \\
\text { MetS associated with two-fold } \\
\text { increased odds of CVD incidence } \\
\text { (OR, 2.04; } 95 \% \text { CI, 1.31-3.17) in } \\
\text { participants with low } \\
\text { MedDiet adherence. }\end{array}$ & $\begin{array}{l}\text { Age, sex, } \\
\text { family history, } \\
\text { smoker, } \\
\text { history of } \\
\text { MetS }\end{array}$ \\
\hline
\end{tabular}

Abbreviations not previously defined: DII, dietary inflammatory index; HR, hazard ratio; CHD, coronary heart disease; ICAM, intercellular adhesion molecule; MACE, major adverse cardiovascular events; MDS, Mediterranean diet score; VCAM, vascular cell adhesion molecule; WHtR, waist to height ratio. 
Table 5. Scientific evidence for health outcomes related to the key CQs on the Mediterranean Diet (MedDiet).

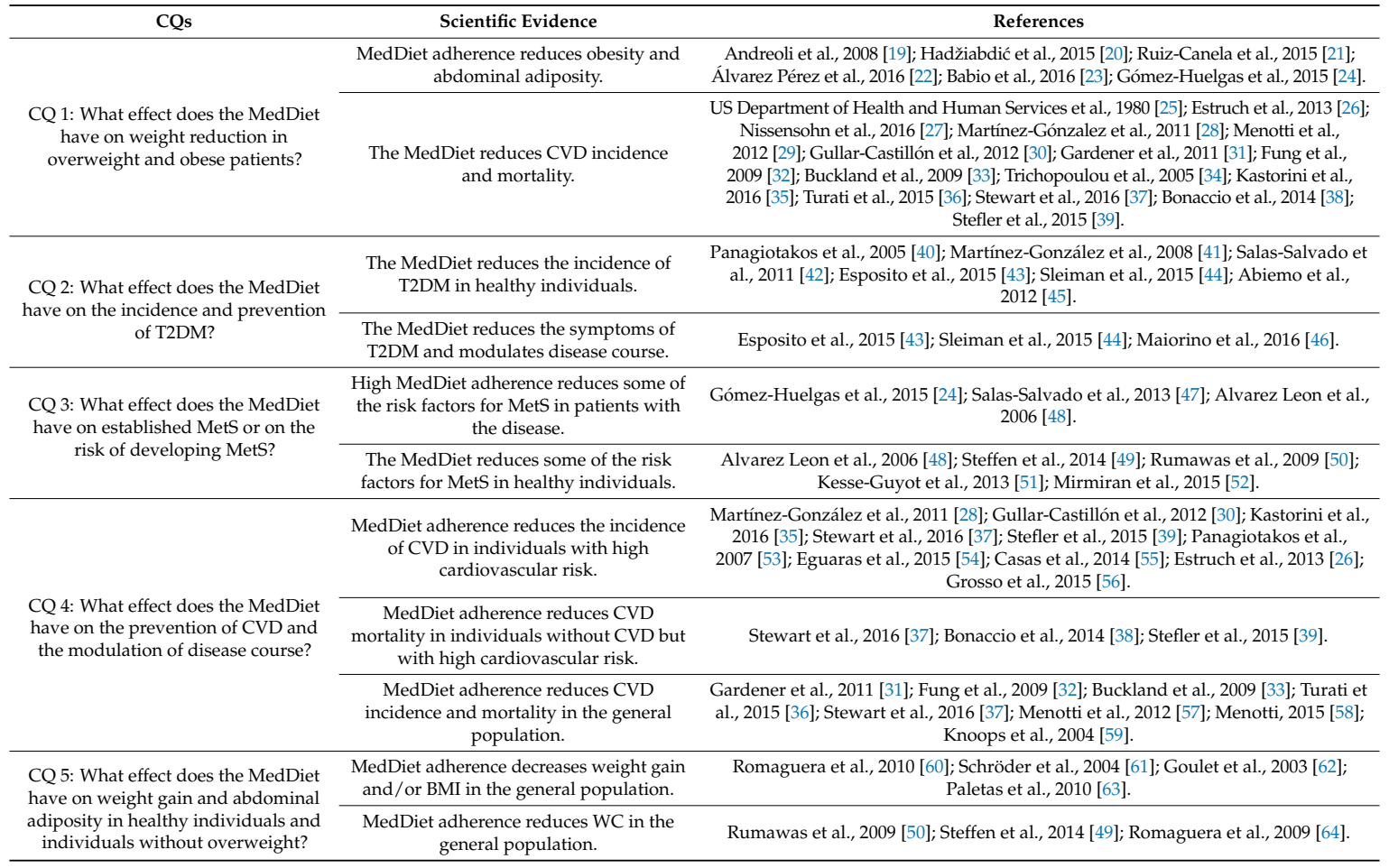

\section{Discussion}

The MedDiet is a well-known, prudent dietary pattern with health benefits supported by an exponentially increasing wealth of scientific evidence. Based on the most recent and accurate scientific evidence available, the aim of this review was to shed light on the therapeutic and preventive effects of the MedDiet on diseases encompassed by the umbrella term cardiodiabesity, in order to inform and guide the development of CPGs for physicians and health professionals. The review addressed five CQs containing key PICO components. The evidence for CQ 1 on the association between the MedDiet and improved health in overweight and obese individuals indicates that it is precisely this population that would benefit the most from the weight loss associated with the MedDiet, and from the additional benefits of a lower risk of CVD incidence and mortality. The evidence for CQ 2, regarding the potential effects of the MedDiet on T2DM incidence and prevention, was moderate. Although some studies provided solid evidence of an effect [40-43], there were discrepancies in relation to the impact of high MedDiet adherence on the risk of T2DM in healthy individuals, and to the reduction of symptoms in those who already had the disease. However, it should be noted that fewer studies have been conducted on the effect of the MedDiet-either through an intervention or simply by measuring adherence to it - on T2DM prevention or amelioration than on other cardiodiabesity outcomes. The evidence for CQ 3, on the association between the MedDiet and MetS, showed that, overall, high adherence was related to decreased risk factors for MetS. The level of evidence was moderate-to-high, although only two studies provided clear evidence of a protective effect in MetS patients. The findings relating to the risk of MetS in healthy individuals were conflicting. The answers to CQ 1 and CQ 4 indicated that overweight and obese individuals who adhered to the MedDiet were most likely to benefit from CVD prevention and disease course modulation. A reduction in CVD incidence and mortality was observed for high-risk individuals and the general population. Considering that CVD is one of the leading causes of morbidity and mortality in Western countries, a medium-term reduction in its incidence would be one of the main benefits of promoting MedDiet adherence. CQ 5 addressed the effect of the MedDiet on weight in non-overweight and non-obese individuals. The resulting evidence, graded as 
moderate-to-high, indicated an inverse relationship between MedDiet adherence and an increase in weight, BMI, and WC.

The evidence used to answer the five CQs was found in 50 articles from the scientific and medical literature on the association between the MedDiet and cardiodiabesity. Twenty of the articles were new and 30 were from the previous review on this topic [6], which found strong evidence of the beneficial effects of MedDiet adherence in patients with CVD, T2DM, MetS, and obesity [6]. From the 37 articles included in the previous paper [6], seven were excluded as they did not meet the inclusion criteria defined in this analysis. Taken together, the 50 articles show strong evidence that the MedDiet plays therapeutic and preventive roles in cardiodiabesity. There was a high level of evidence showing that MedDiet adherence improves the health of overweight and obese patients by reducing weight and WC, and lowering CVD incidence and mortality [19-39]. Moderate evidence of a preventive effect of the MedDiet on T2DM was found for patients with the disease, and in individuals with and without risk factors [40-46]. Evidence of the preventive and therapeutic roles of MedDiet adherence was moderate-to-high for MetS [24,47-52] and high for CVD risk. Individuals with risk factors and the general population benefited from a reduction in CVD incidence and mortality [28,30-33,35-39,53-59], thus supporting previous meta-analysis findings [57]. The association between MedDiet adherence and low weight gain, BMI, and WC in non-obese individuals was supported by low-to-high evidence [49,50,60-64]. Many mechanisms underlying the beneficial effects of the MedDiet have been described elsewhere and are mainly related to improvements in lipid profile, oxidative stress, inflammation status, glucose metabolism, vascular integrity, and effects on hormone status and gut microbiota-mediated metabolic health, amongst others [4].

Regarding its beneficial effects on cardiovascular health, higher MedDiet adherence has been shown to improve complex processes relating to atherosclerosis, such as the atherogenicity of LDLs or the functionality of HDLs. In the latter case, this is particularly so when the MedDiet is supplemented with virgin olive oil. Epidemiological trials from the 1960s suggested that MedDiet adherence was associated with decreased rates of CVD. Many studies have demonstrated a mortality benefit from a Mediterranean or Mediterranean-like diet after MI. One example is the Lyon Diet Heart Study [67], which showed that a MedDiet reduced recurrent cardiovascular events by $50 \%-70 \%$ among MI patients. However, the role of the MedDiet in the primary prevention of CVD had not been well established until the PREDIMED trial. That trial randomized 7447 Spanish patients at high risk for CVD to one of three diets: (1) A MedDiet supplemented with extra-virgin olive oil; (2) a MedDiet supplemented with nuts; or (3) a control diet encouraging the intake of low-fat foodstuffs [26]. In both MedDiet groups, there was a statistically significant reduction in the rate of the composite primary outcome of MI, stroke, or cardiovascular death after more than four years. Regarding the strength of the association, there was a $30 \%$ absolute reduction in the incidence of major CVD events in the MedDiet groups. These findings were consistent with the previous large body of observational scientific evidence, and potential confounders as alternative explanations were discarded. A dose-response gradient was observed, whereby greater MedDiet adherence showed increased protection. Every two-point increase in adherence was associated with a $25 \%$ reduction in CVD. The results were consistent with the known facts and accepted paradigms for the natural history and biology of CVD. The beneficial effects on surrogate markers of CVD risk added to the consistency. The epidemiological evidence of low CHD rates in Mediterranean countries also supports a protective effect of the MedDiet. Regarding experimental evidence, the PREDIMED RCT was intensively scrutinized in 2018 after certain comments on the randomization procedures led to the study being retracted and republished by the same research group $[26,68]$. In the assessment of the quality of the RCT, inappropriate allocation concealment was among the reasons noted [69]. The authors performed several complicated analyses to attempt to control for these deficiencies, which all seemed to confirm the original findings of that study. Thus, the updated publication documented similar findings, but the authors were unable to confirm adherence to randomization schemes, given that documentation was missing (supplemental appendix 
of [26]). Other high-quality dietary patterns such as the Dietary Approaches to Stop Hypertension (DASH) diet [70] and the prudent healthy pattern measured by the Healthy Eating Index [71] have also been associated with a reduced incidence of CVD events. However, the evidence collected and analyzed for these patterns is not as robust as the evidence provided by PREDIMED.

The aim of this study was to analyze the effects of the MedDiet as a diet and lifestyle, and not the effects of specific types of food. Studies focusing on the benefits of specific food groups in patients with cardiodiabesity were therefore excluded, even though some showed evidence of very strong preventive and therapeutic effects. Consumption of dairy fat, for instance, has been linked to a low incidence of MetS, while that of whole and skimmed cheese has been linked to a higher risk of MetS, and that of whole yogurt to a decrease in all the risk factors for MetS [72]. Indeed, while there have been concerns about a diet's fat content since the last century, a number of reviews have shown that a low-fat diet is not effective at preventing cardiometabolic disease [73]. A direct association has also been observed between the consumption of tea and coffee and a lower incidence of MetS within the context of the MedDiet [74]. In another study of individuals with a moderate cardiovascular risk, moderate consumers of red wine had a lower risk of MetS than non-drinkers [75]. Interestingly, this effect was more pronounced in women. The consumption of sugary drinks has been linked to increased WC [76,77]. Mozaffarian et al. [78] conducted an in-depth review of the role of the main components of the MedDiet and other widely consumed foods in relation to health status. Their findings supported the widely agreed beneficial effects of fruit, nuts, fish, vegetables, vegetable oils, whole grains, beans, and yogurt, and the harmful effects of refined grains, starches, sugars, processed meats, high-sodium foods, and trans-fat foodstuffs. Foodstuffs for which there are still no proven beneficial or harmful effects include cheese, eggs, poultry, milk, butter, and unprocessed red meat. Albeit indirectly, the findings of this review show the benefits of the main components of the MedDiet. As called for by previous studies, the relative effects of specific food groups need further investigation $[6,55,58,65,66]$.

Our study has some limitations. Although some of the studies analyzed in the review did not find a strong association between MedDiet adherence and the main outcomes analyzed, they did find positive links to intermediate risk factors. Certain discrepancies could be due to numerous aspects relating to the inherent limitations of the different studies.

In addition, when analyzing the literature, it is necessary to be aware of the different confounders and indices to ensure appropriate quantitative and/or qualitative measures [79]. The likelihood of heterogeneous measures of cause and effect should also be taken into account when interpreting the association between the MedDiet and the different health outcomes, as has been done in two recent meta-analyses that corroborate the results of the PICO analysis [80]. The level of heterogeneity of the included studies is also our concern.

This study is based on the 2014 study of the association between the MedDiet and cardiodiabesity by García-Fernández et al. [6]. The literature review was updated using the same search and a similar methodology to address a series of CQs based on scientific evidence on the association between the MedDiet and cardiodiabesity, with a view to informing future CPGs on how to treat and prevent obesity, MetS, T2DM, and CVD. The evidence uncovered provides solid support of an inverse relationship between MedDiet adherence and cardiodiabesity outcomes.

\section{Conclusions}

Recent scientific evidence has shown that the MedDiet, which is listed as a UNESCO (United Nations Educational, Scientific and Cultural Organization) Intangible Cultural Heritage of Humanity [81,82] and referred to in the 2015-2020 American dietary guidelines [83] as an example of a healthy eating pattern, has a beneficial effect on health and sustainability. It also has an important social component $[84,85]$. The scientific basis for developing evidence-based CPGs consistent with international standards, such as those promoted by the Scottish Intercollegiate Guidelines Network (SIGN) and the United Kingdom's National Institute for Health and Care Excellence (NICE), has been 
provided. The reviewed studies show strong evidence of an association between MedDiet adherence and outcomes in cardiodiabesity, which encompasses CVD, T2DM, MetS, and obesity. The MedDiet plays a role in obesity and MetS prevention in healthy or at-risk individuals, and in mortality risk reduction in overweight or obese individuals. Furthermore, it decreases the incidence of T2DM and CVD in healthy individuals, and reduces the severity of symptoms in individuals that already have those diseases. The scientific evidence seems to support the conclusion that MedDiet adherence is a preventive and therapeutic tool for cardiodiabesity.

Author Contributions: Conceptualization, M.F. and A.B.-F.; methodology, M.F., E.G.-F., and A.B.-F.; validation, A.A.-M., F.X.M., and L.S.-M.; investigation, M.F., E.G.-F., and L.R.; resources, A.B.-F., A.A.-M., and F.X.M.; writing-original draft preparation, M.F., E.G.-F., L.R., and A.B.; writing-review and editing, G.P.-B. and L.S.-P.; visualization, F.M., L.S.-P., and G.P.-B.; supervision, A.B.-F. and L.S.-M.

Funding: This research received no external funding.

Conflicts of Interest: The authors declare no conflict of interest.

\section{References}

1. Sofi, F.; Cesari, F.; Abbate, R.; Gensini, G.F.; Casini, A. Adherence to Mediterranean diet and health status: Meta-Analysis. BMJ 2008, 337, a1344. [CrossRef] [PubMed]

2. Martinez-Gonzalez, M.A.; Bes-Rastrollo, M.; Serra-Majem, L.; Lairon, D.; Estruch, R.; Trichopoulou, A. Mediterranean food pattern and the primary prevention of chronic disease: Recent developments. Nutr. Rev. 2009, 67, S111-S116. [CrossRef]

3. Trichopoulou, A. From research to education: The Greek experience. Nutrition 2000, 16, 528-531. [CrossRef]

4. Tosti, V.; Bertozzi, B.; Fontana, L. Health benefits of the Mediterranean diet: Metabolic and molecular mechanisms. J. Gerontol. A Biol. Sci. Med. Sci. 2018, 73, 318-326. [CrossRef] [PubMed]

5. Robertson, D. Cardiodiabetes-Is a joint approach the way forward? Br. J. Cardiol. 2008, 15, S8-S10.

6. Garcia-Fernandez, E.; Rico-Cabanas, L.; Rosgaard, N.; Estruch, R.; Bach-Faig, A. Mediterranean diet and cardiodiabesity: A review. Nutr. Rev. 2014, 6, 3474-3500. [CrossRef]

7. International Diabetes Federation. IDF Diabetes Atlas, 8th ed.; International Diabetes Federation: Brussels, Belgium, 2017; Available online: http:/ / www.diabetesatlas.org (accessed on 30 January 2018).

8. Di Cesare, M.; Bentham, J.; Stevens, G.; Zhou, B.; Danaei, G.; Lu, Y.; Bixby, H.; Cowan, M.J.; Riley, L.M.; Hajifathalian, K.; et al. Trends in adult body-mass index in 200 countries from 1975 to 2014: A pooled analysis of 1698 population-based measurement studies with 19.2 million participants. Lancet 2016, 387, 1377-1396.

9. Bach-Faig, A.; Berry, E.M.; Lairon, D.; Reguant, J.; Trichopoulou, A.; Dernini, S.; Medina, F.X.; Battino, M.; Belahsen, R.; Miranda, G.; et al. Mediterranean diet pyramid today. Science and cultural updates. Public Health Nutr. 2011, 14, 2274-2284. [CrossRef]

10. Millen, B.E.; Abrams, S.; Adams-Campbell, L.; Anderson, C.A.; Brenna, J.T.; Campbell, W.W.; Clinton, S.; Hu, F.; Nelson, M.; Neuhouser, M.L.; et al. The 2015 Dietary Guidelines Advisory Committee Scientific Report: Development and Major Conclusions. Adv. Nutr. 2016, 7, 438-444. [CrossRef]

11. Dinu, M.; Pagliai, G.; Casini, A.; Sofi, F. Mediterranean diet and multiple health outcomes: An umbrella review of meta-analyses of observational studies and randomized trials. Eur. J. Clin. Nutr. 2018, 72, 30-43. [CrossRef]

12. Popkin, B.M. The nutrition transition in the developing world. Dev. Policy. Rev. 2003, 21, 581-597. [CrossRef]

13. Popkin, B.M.; Gordon-Larsen, P. The nutrition transition: Worldwide obesity dynamics and their determinants. Int. J. Obes. 2004, 28, s2. [CrossRef]

14. Sentenach-Carbo, A.; Batlle, C.; Franquesa, M.; García-Fernandez, E.; Rico, L.; Shamirian-Pulido, L.; Pérez, M.; Deu-Valenzuela, E.; Ardite, E.; Funtikova, A.N.; et al. Adherence of Spanish Primary Physicians and Clinical Practise to the Mediterranean Diet. Eur. J. Clin. Nutr. 2018. [CrossRef]

15. Popkin, B.M.; Duffey, K.; Gordon Larsen, P. Environmental influences on food choice, physical activity and energy balance. Physiol. Behav. 2005, 86, 603-613. [CrossRef] 
16. Institute of Medicine (US) Committee to Advise the Public Health Service on Clinical Practice Guidelines. Clinical Practice Guidelines: Directions for a New Program; Field, M.J., Lohr, K.N., Eds.; National Academies Press: Washington, DC, USA, 1990. Available online: https:/ /www.ncbi.nlm.nih.gov/books/NBK235751/ doi:10.17226/1626 (accessed on 20 July 2017).

17. Brouwers, M.C.; Kho, M.E.; Browman, G.P.; Burgers, J.S.; Cluzeau, F.; Feder, G.; Fervers, B.; Graham, I.D.; Grimshaw, J.; Hanna, S.E.; et al. AGREE II: Advancing guideline development, reporting and evaluation in healthcare. Can. Med. Assoc. 2010, 182, 839-842. [CrossRef]

18. Working Group for CPG Updates. Updating Clinical Practice Guidelines in the National Health System: Methodology Handbook. National Health System Quality Plan of the Spanish Ministry of Health and Social Policy. Aragon Health Sciences Institute (I+CS) Clinical Practice Guidelines in the National Health System: I+CS No.2007/02-01. 2009. Available online: http:/ /www.guiasalud.es/emanuales/traduccion/ ingles/manual_actualizacion/documentos/MMA_VersionEnglish_DEFINITIVA_10122_FIN.pdf (accessed on 20 July 2017).

19. Andreoli, A.; Lauro, S.; di Daniele, N.; Sorge, R.; Celi, M.; Volpe, S.L. Effect of a moderately hypoenergetic Mediterranean diet and exercise program on body cell mass and cardiovascular risk factors in obese women. Eur. J. Clin. Nutr. 2008, 62, 892-897. [CrossRef]

20. Hadžiabdić, M.O.; Vitali Cepo, D.; Rahelić, D.; Božikov, V. The Effect of the Mediterranean Diet on Serum Total Antioxidant Capacity in Obese Patients: A Randomized Controlled Trial. J. Am. Coll. Nutr. 2015, 35, 224-351. [CrossRef]

21. Ruiz-Canela, M.; Zazpe, I.; Shivappa, N.; Hébert, J.R.; Sanchez-Tainta, A.; Corella, D.; Salas-Salvadó, J.; Fito, M.; Lamuela-Raventos, R.M.; Rekondo, J.; et al. Dietary inflammatory index and anthropometric measures of obesity in a population sample at high cardiovascular risk from the PREDIMED (PREvención con DIeta MEDiterránea) trial. Br. J. Nutr. 2015, 113, 984-995. [CrossRef]

22. Álvarez-Pérez, J.; Sánchez-Villegas, A.; Díaz-Benítez, E.M.; Ruano-Rodríguez, C.; Corella, D.; Martínez-González, M.Á.; Estruch, R.; Salas-Salvadó, J.; Serra-Majem, L. Influence of a Mediterranean Dietary Pattern on Body Fat Distribution: Results of the PREDIMED-Canarias Intervention Randomized Trial. J. Am. Coll. Nutr. 2016, 35, 568-580. [CrossRef]

23. Babio, N.; Toledo, E.; Estruch, R.; Ros, E.; Martínez-González, M.A.; Castañer, O.; Bulló, M.; Corella, D.; Arós, F.; Gómez-Gracia, E.; et al. Mediterranean diets and metabolic syndrome status PREDIMED in the randomized trial. CMAJ 2014, 186, 649-657. [CrossRef]

24. Gómez-Huelgas, R.; Short-Jansen, S.; Baca-Osorio, A.J.; Mancera-Romero, J.; Tinahones, F.J.; Bernal-Lopez, M.R. Effects of long-term lifestyle intervention with Mediterranean diet and exercise program for the Management of Patients with metabolic syndrome in a primary care setting. Eur. J. Intern. Med. 2015, 26, 317-323. [CrossRef] [PubMed]

25. US Department of Health and Human Services; US Department of Agriculture. Nutrition and Your Health: Dietary Guidelines for Americans [Internet]. 1st Edition. 1980. Available online: http://health.gov/ dietaryguidelines/1980thin.pdf (accessed on 1 August 2017).

26. Estruch, R.; Ros, E.; Salas-Salvadó, J.; Covas, M.I.; Corella, D.; Arós, F.; Gómez-Gracia, E.; Ruiz-Gutiérrez, V.; Fiol, M.; Lapetra, J.; et al. Primary prevention of cardiovascular disease with a Mediterranean diet. N. Engl. J. Med. 2018, 368, 1279-1290. Retraction and republication in 2018, 378, 2441-2442. [CrossRef]

27. Nissensohn, M.; Viñas-Román, B.; Sánchez-Villegas, A.; Piscopo, S.-; Serra-Majem, L. The Effect of the Mediterranean Diet on Hypertension: A Systematic Review and Meta-Analysis. J. Nutr. Educ. Behav. 2016, 48, 42-53. [CrossRef] [PubMed]

28. Martínez-González, M.A.; García-López, M.; Bes-Rastrollo, M.; Toledo, E.; Martínez-Lapiscina, E.H.; Delgado-Rodriguez, M.; Vazquez, Z.; Benito, S.; Beunza, J.J. Mediterranean diet and the incidence of cardiovascular disease: A Spanish cohort. Nutr. Metab. Cardiovasc. Dis. 2011, 21, 237-244. [CrossRef] [PubMed]

29. Menotti, A.; Alberti-Fidanza, A.; Fidanza, F.; Lantian, M.; Fruttini, D. Factor analysis in the identification of dietary patterns and their predictive role in morbid and fatal events. Public Health Nutr. 2012, 15, 1232-1239. [CrossRef]

30. Guallar-Castillón, P.; Rodríguez-Artalejo, F.; Tormo, M.J.; Sánchez, M.J.; Rodríguez, L.; Quirós, J.R.; Navarro, C.; Molina, E.; Martínez, C.; Marín, P.; et al. Major dietary patterns and risk of coronary heart disease in middle-aged persons from a Mediterranean country: The EPIC-Spain cohort study. Nutr. Metab. Cardiovasc. Dis. 2012, 22, 192-199. [CrossRef] 
31. Gardener, H.; Wright, C.B.; Gu, Y.; Demmer, R.T.; Boden-Albala, B.; Elkind, M.S.; Sacco, R.L.; Scarmeas, N. Mediterranean-style diet and risk of ischemic stroke, myocardial infarction, and vascular death: The Northern Manhattan Study. Am. J. Clin. Nutr. 2011, 94, 1458-1464. [CrossRef] [PubMed]

32. Fung, T.T.; Rexrode, K.M.; Mantzoros, C.S.; Manson, J.E.; Willett, W.C.; Hu, F.B. Mediterranean diet and incidence of and mortality from coronary heart disease and stroke in women. Circulation 2009, 119, 1093-1100. [CrossRef]

33. Buckland, G.; González, C.A.; Agudo, A.; Vilardell, M.; Berenguer, A.; Amiano, P.; Ardanaz, E.; Arriola, L.; Barricarte, A.; Basterretxea, M.; et al. Adherence to the Mediterranean diet and risk of coronary heart disease in the Spanish EPIC Cohort Study. Am. J. Epidemiol. 2009, 170, 1518-1529. [CrossRef]

34. Trichopoulou, A.; Naska, A.; Orfanos, P.; Trichopoulos, D. Mediterranean diet in relation to body mass index and waist-to-hip ratio: The Greek European Prospective Investigation into Cancer and Nutrition Study. Am. J. Clin. Nutr. 2005, 82, 935-940. [CrossRef]

35. Kastorini, C.-M.; Panagiotakos, D.B.; Chrysohoou, C.; Georgousopoulou, E.; Pitaraki, E.; Puddu, P.E.; Tousoulis, D.; Stefanadis, C.; Pitsavos, C. Metabolic syndrome, adherence to the Mediterranean diet and 10-year cardiovascular disease incidence: The ATTICA study. Atherosclerosis 2016, 246, 87-93. [CrossRef]

36. Turati, F.; Dilis, V.; Rossi, M.; Lagiou, P.; Benetou, V.; Katsoulis, M.; Naska, A.; Trichopoulos, D.; La Vecchia, C.; Trichopoulou, A. Glycemic load and coronary heart disease in a Mediterranean population: The Greek EPIC cohort study. Nutr. Metab. Cardiovasc. Dis. 2015, 25, 336-342. [CrossRef] [PubMed]

37. Stewart, R.A.; Wallentin, L.; Benatar, J.; Danchin, N.; Hagström, E.; Held, C.; Husted, S.; Lonn, E.; Stebbins, A.; Chiswell, K.; et al. Dietary patterns and the risk of major adverse cardiovascular events in a global study of high-risk Patients with stable coronary heart disease. Eur. Heart J. 2016, 37, 1993-2001. [CrossRef] [PubMed]

38. Bonaccio, M.M.; Di Castelnuovo, A.; Costanzo, S.; Persichillo, M.; Donati, M.B.; De Gaetano, G.; Iacoviello, L. Adherence to the Mediterranean diet is associated with reduced overall mortality in subjects with diabetes. Prospective results from the Moli-sani study. Eur. J. Cardiol. Prev. 2014, 21, S55.

39. Stefler, D.; Malyutina, S.; Kubinova, R.; Pajak, A.; Peasey, A.; Pikhart, H.; Brunner, E.J.; Bobak, M. Mediterranean diet score and total and cardiovascular mortality in Eastern Europe: The HAPIEE study. Eur. J. Nutr. 2015, 56, 421-429. [CrossRef] [PubMed]

40. Panagiotakos, D.B.; Pitsavost, C.; Chrysohoou, C.; Stefanadis, C. The epidemiology of Type 2 diabetes mellitus in adults Greek: The ATTICA study. Diabet. Med. 2005, 22, 1581-1588. [CrossRef]

41. Martínez-González, M.A.; de la Fuente-Arrillaga, C.; Nunez-Cordoba, J.M.; Basterra-Gortari, F.J.; Beunza, J.J.; Vazquez, Z.; Benito, S.; Tortosa, A.; Bes-Rastrollo, M. Adherence to Mediterranean diet and risk of developing diabetes: Prospective cohort study. BMJ 2008, 336, 1348-1351. [CrossRef] [PubMed]

42. Salas-Salvadó, J.; Bulló, M.; Babio, N.; Martínez-González, M.Á.; Ibarrola-Jurado, N.; Basora, J.; Estruch, R.; Covas, M.I.; Corella, D.; Arós, F.; et al. PREDIMED Study Investigators. Reduction in the incidence of type 2 diabetes with the Mediterranean diet: Results of the PREDIMED-Reus nutrition intervention randomized trial. Diabetes Care 2011, 34, 14-19.

43. Esposito, K.; Maiorino, M.I.; Bellastella, G.; Chiodini, P.; Panagiotakos, D.; Giugliano, D. A journey into a Mediterranean diet and type 2 diabetes: A systematic review with meta-analysis. BMJ Open 2015, 5, e008222. [CrossRef]

44. Sleiman, D.; Al-Badri, M.R.; Azar, S.T. Effect of Mediterranean diet in diabetes control and cardiovascular risk modification: A systematic review. Front. Public Health 2015, 3, 69. [CrossRef]

45. Abiemo, E.E.; Alonso, A.; Nettleton, J.A.; Steffen, L.M.; Bertoni, A.G.; Jain, A.; Lutsey, P.L. Relationships of the Mediterranean dietary pattern with insulin resistance and diabetes incidence in the Multi-Ethnic Study of Atherosclerosis (MESA). Br. J. Nutr. 2013, 109, 1490-1497. [CrossRef] [PubMed]

46. Maiorino, M.I.; Bellastella, G.; Petrizzo, M.; Scappaticcio, L.; Giugliano, D.; Esposito, K. Anti-inflammatory Effect of Mediterranean Diet in Type 2 Diabetes Is Durable: 8-Year Follow-up of a Controlled Trial. Diabetes Care 2016, 39, 44-45. [CrossRef]

47. Salas-Salvado, J.; Martin, M.; Ruiz-Gutie, V. Effect of a Mediterranean diet supplemented with nuts on metabolic syndrome status. Arch. Inter. Med. 2013, 168, 2449-2458. [CrossRef] [PubMed]

48. Alvarez León, E.; Henríquez, P.; Serra-Majem, L. Mediterranean diet and metabolic syndrome: A cross-sectional study in the Canary Islands. Public Health Nutr. 2006, 9, 1089-1098. [CrossRef] [PubMed] 
49. Steffen, L.M.; Van Horn, L.; Daviglus, M.L.; Zhou, X.; Reis, J.P.; Loria, C.M.; Jacobs, D.R.; Duffey, K.J. A modified Mediterranean diet score is associated with a lower risk of incident metabolic syndrome over 25 years among young adults: The CARDIA (Coronary Artery Risk Development in Young Adults) study. Br. J. Nutr. 2014, 112, 1654-1661. [CrossRef] [PubMed]

50. Rumawas, M.E.; Meigs, J.B.; Dwyer, J.T.; McKeown, N.M.; Jacques, P.F. Mediterranean-style dietary pattern, reduced risk of metabolic syndrome traits, and incidence in the Framingham Offspring Cohort. Am. J. Clin. Nutr. 2009, 90, 1608-1614. [CrossRef] [PubMed]

51. Kesse-Guyot, E.; Ahluwalia, N.; Lassale, C.; Hercberg, S.; Fezeu, L.; Lairon, D. Adherence to Mediterranean diet reduces the risk of metabolic syndrome: A 6-year prospective study. Nutr. Metab. Cardiovasc. Dis. 2013, 23, 677-683. [CrossRef]

52. Mirmiran, P.; Moslehi, N.; Mahmoudof, H.; Sadeghi, M.; Azizi, F. A Longitudinal Study of Adherence to the Mediterranean Dietary Pattern and Metabolic Syndrome in a Mediterranean Non-Population. Int. J. Endocrinol. Metab. 2015, 13, 1-8. [CrossRef] [PubMed]

53. Panagiotakos, D.B.; Polystipioti, A.; Papairakleous, N.; Polychronopoulos, E. Long-Term adoption of a Mediterranean diet is associated with a better health status in elderly people; a cross-sectional survey in Cyprus. Asia Pac. J. Clin. Nutr. 2007, 16, 331-337. [PubMed]

54. Eguaras, S.; Toledo, E.; Buil-Cosiales, P.; Salas-Salvadó, J.; Corella, D.; Gutierrez-Bedmar, M.; Santos-Lozano, J.M.; Arós, F.; Fiol, M.; Fitó, M.; et al. Does the Mediterranean diet counteract the adverse effects of abdominal adiposity? Nutr. Metabo. Cardiovasc. Dis. 2015, 25, 569-574. [CrossRef] [PubMed]

55. Casas, R.; Sacanella, E.; Urpí-Sardà, M.; Chiva-Blanch, G.; Ros, E.; Martínez-González, M.A.; Covas, M.I.; Lamuela-Raventos, R.M.; Salas-Salvadó, J.; Fiol, M.; et al. The effects of the Mediterranean diet on biomarkers of vascular wall inflammation and plaque vulnerability in subjects with high risk for cardiovascular disease. A randomized trial. PLoS ONE 2014, 9, e100084. [CrossRef]

56. Grosso, G.; Marventano, S.; Yang, J.; Micek, A.; Pajak, A.; Scalfi, L.; Galvano, F.; Kales, S.N. A comprehensive meta-analysis on evidence of Mediterranean diet and cardiovascular disease: Are individual components equal? Crit. Rev. Food Sci. Nutr. 2015, 57, 3218-3232. [CrossRef]

57. Menotti, A.; Alberti-Fidanza, A.; Fidanza, F. The association of the Mediterranean Adequacy Index with fatal coronary events in an Italian middle-aged male population followed for 40 years. Nutr. Metab. Cardiovasc. Dis. 2012, 22, 369-375. [CrossRef]

58. Menotti, A.; Puddu, P.E.; Maiani, G.; Catasta, G. Lifestyle behaviour and lifetime incidence of heart diseases. Int. J. Cardiol. 2015, 201, 293-299. [CrossRef]

59. Knoops, K.T.; de Groot, L.C.; Kromhout, D.; Perrin, A.E.; Moreiras-Varela, O.; Menotti, A.; van Staveren, W.A. Mediterranean diet, lifestyle factors, and 10-year mortality in elderly European men and women: The HALE project. JAMA 2004, 292, 1433-1439. [CrossRef]

60. Romaguera, D.; Norat, T.; Vergnaud, A.C.; Mouw, T.; May, A.M.; Agudo, A.; Buckland, G.; Slimani, N.; Rinaldi, S.; Couto, E.; et al. Mediterranean dietary patterns and prospective weight change in participants of the EPIC-PANACEA project. Am. J. Clin. Nutr. 2010, 92, 912-921. [CrossRef]

61. Schröder, H.; Marrugat, J.; Vila, J.; Covas, M.I.; Elosua, R. Adherence to the traditional Mediterranean diet is inversely associated with body mass index and obesity in a Spanish population. J. Nutr. 2004, 134, 3355-3361. [CrossRef]

62. Goulet, J.; Lamarche, B.; Nadeau, G.; Lemieux, S. Effect of a nutritional intervention promoting the Mediterranean food pattern on plasma lipids, lipoproteins and body weight in healthy French-Canadian women. Atherosclerosis 2003, 170, 115-124. [CrossRef]

63. Paletas, K.; Athanasiadou, E.; Sarigianni, M.; Paschos, P.; Kalogirou, A.; Hassapidou, M.; Tsapas, A. The protective role of the Mediterranean diet on the prevalence of metabolic syndrome in a population of Greek obese subjects. J. Am. Coll. Nutr. 2010, 29, 41-45. [CrossRef]

64. Romaguera, D.; Norat, T.; Mouw, T.; May, A.M.; Bamia, C.; Slimani, N.; Travier, N.; Besson, H.; Luan, J.; Wareham, N. Adherence to the Mediterranean diet is associated with lower abdominal adiposity in European men and women. J. Nutr. 2009, 139, 1728-1737. [CrossRef]

65. Trichopoulou, A.; Costacou, T.; Bamia, C.; Trichopoulos, D. Adherence to a Mediterranean diet and survival in a Greek population. N. Engl. J. Med. 2003, 348, 2599-2608. [CrossRef] [PubMed] 
66. Sofi, F.; Macchi, C.; Abbate, R.; Gensini, G.F.; Casini, A. Mediterranean diet and health status: An updated meta-analysis and a proposal for a literature-based adherence score. Public Health Nutr. 2013, 29, 1-14. [CrossRef]

67. De Lorgeril, M.; Salen, P.; Martin, J.L.; Monjaud, I.; Delaye, J.; Mamelle, N. Mediterranean diet, traditional risk factors, and the rate of cardiovascular complications after myocardial infarction: Final report of the Lyon Diet Heart Study. Circulation 1999, 99, 779-785. [CrossRef] [PubMed]

68. Estruch, R.; Ros, E.; Salas-Salvadó, J.; Covas, M.I.; Corella, D.; Arós, F.; Gómez-Gracia, E.; Ruiz-Gutiérrez, V.; Fiol, M.; Lapetra, J.; et al. Primary prevention of cardiovascular disease with a Mediterranean diet supplemented with extra-virgin olive oil or nuts. N. Engl. J. Med. 2018, 378, e34. [CrossRef] [PubMed]

69. Jüni, P.; Altman, D.G.; Egger, M. Systematic reviews in health care: Assessing the quality of controlled clinical trials. BMJ 2001, 323, 42-46. [CrossRef]

70. Chiavaroli, L.; Viguiliouk, E.; Nishi, S.K.; Mejia, S.B.; Rahelić, D.; Kahleová, H.; Salas-Salvadó, J.; Kendall, C.W.; Sievenpiper, J.L. DASH Dietary Pattern and Cardiometabolic Outcomes: An Umbrella Review of Systematic Reviews and Meta-Analyses. Nutrients 2019, 11, 338. [CrossRef] [PubMed]

71. Onvani, S.; Haghighatdoost, F.; Surkan, P.J.; Larijani, B.; Azadbakht, L. Adherence to the healthy eating index and alternative healthy eating index patterns and mortality from all causes, cardiovascular disease and cancer: A meta-analysis of observational studies. J. Hum. Nutr. Diet. 2017, 30, 216-226. [CrossRef]

72. Babio, N.; Becerra-Tomás, N.; Martínez-González, M.Á.; Corella, D.; Estruch, R.; Ros, E.; Sayón-Orea, C.; Fitó, M.; Serra-Majem, L.; Arós, F.; et al. Consumption of Yogurt, Low-Fat Milk, and Other Low-Fat Dairy Products Is Associated with Lower Risk of Metabolic Syndrome Incidence in an Elderly Mediterranean Population. J. Nutr. 2015, 145, 2308-2316.

73. Billingsley, H.E.; Carbone, S.; Lavie, C.J. Dietary Fats and Chronic Noncommunicable Diseases. Nutrients 2018, 10, 1385. [CrossRef]

74. Grosso, G.; Marventano, S.; Galvano, F.; Pajak, A.; Mistretta, A. factors associated with metabolic syndrome in a Mediterranean population: Role of caffeinated beverages. J. Epidemiol. 2014, 24, 327-333. [CrossRef]

75. Tresserra-Rimbau, A.; Medina-Remón, A.; Lamuela-Raventós, R.M.; Bulló, M.; Salas-Salvadó, J.; Corella, D.; Fitó, M.; Gea, A.; Gómez-Gracia, E.; Lapetra, J.; et al. Moderate red wine consumption is associated with a lower prevalence of the metabolic syndrome in the PREDIMED population. Br. J. Nutr. 2015, 113, S121-S130. [CrossRef] [PubMed]

76. Ros, E.; Santos-lozano, M. Frequent Consumption of Sugar- and Artificially Sweetened Beverages and Natural and Bottled Fruit Juices Is Associated with an Increased Risk of Metabolic Syndrome in a Mediterranean Population at High Cardiovascular Disease. J. Nutr. 2016, 46, 1528-1536.

77. Funtikova, A.N.; Subirana, I.; Gomez, S.F.; Fitó, M.; Elosua, R.; Benítez-Arciniega, A.A.; Schröder, H. Soft Drink Consumption Is Positively Associated with Increased Waist Circumference and 10-Year Incidence of Abdominal Obesity in Spanish Adults. J. Nutr. 2014, 145, 328-334. [CrossRef] [PubMed]

78. Mozaffarian, D. Dietary and Policy Priorities for Cardiovascular Disease, Diabetes, and Obesity: A Comprehensive Review. Circulation 2016, 133, 187-225. [CrossRef] [PubMed]

79. Zaragoza-Martí, A.; Cabañero-Martínez, M.J.; Hurtado-Sánchez, J.A.; Laguna-Pérez, A.; Ferrer-Cascales, R. Evaluation of Mediterranean diet adherence scores: A systematic review. BMJ Open 2018, 8, e019033. [CrossRef] [PubMed]

80. Malmir, H.; Saneei, P.; Larijani, B.; Esmaillzadeh, A. Adherence to Mediterranean diet in relation to bone mineral density and risk of fracture: A systematic review and meta-analysis of observational studies. Eur. J. Nutr. 2018, 57, 2147-2160. [CrossRef] [PubMed]

81. Serra-Majem, L.; Medina, F.X. The Mediterranean Diet as an Intangible and Sustainable Food Culture. In The Mediterranean Diet: An Evidence-Based Approach, 1st ed.; Preedy, V.R., Watson, D.R., Eds.; Academic Press-Elsevier: London, UK, 2015; pp. 37-46.

82. Medina, F.X. Mediterranean Diet, Culture and Heritage: Challenges for a New Conception. Public Health Nutr. 2009, 12, 1618-1620. [CrossRef]

83. 2015-2020 Dietary Guidelines. Healthy Mediterranean-Style Eating Pattern [Internet]. Available online: https: / / health.gov / dietaryguidelines/2015/guidelines/chapter-1/examples-of-other-healthy-eating-patterns / (accessed on 1 February 2019). 
84. Dernini, S.; Berry, E.; Serra-Majem, L.; La Vecchia, C.; Capone, R.; Medina, F.X.; Trichopoulou, A. Med Diet 4.0: The Mediterranean diet with four sustainable benefits. Public Health Nutr. 2017, 20, 1322-1330. [CrossRef]

85. Medina, F.X.; Aguilar, A.; Solé-Sedeno, J.M. Aspectos sociales y culturales sobre la obesidad: Reflexiones necesarias desde la salud pública. Nutr. Clin. Diet. Hosp. 2014, 34, 67-71.

(C) 2019 by the authors. Licensee MDPI, Basel, Switzerland. This article is an open access article distributed under the terms and conditions of the Creative Commons Attribution (CC BY) license (http://creativecommons.org/licenses/by/4.0/). 